\title{
ANALIZA SVJETSKOG I HRVATSKOG TRŽIŠTA SVINJSKOG MESA
}

\author{
ANALYSIS OF THE WORLD AND CROATIAN PORK MARKET
}

\author{
I. Stupnišek, Željka Mesić
}

\section{SAŽETAK}

Cilj rada bio je utvrditi stanje na svjetskom i hrvatskom tržištu svinjskog mesa. Za prikaz hrvatskog tržišta svinjskog mesa korištena je metoda proizvodno - potrošnih bilanci sukladno metodologiji Statističkog ureda europskih zajednica, podaci Državnog zavoda za statistiku (DZS) i FAOSTATa. Za analizu svjetskog i EU tržišta svinjskog mesa korišteni su podaci FAOSTAT-a. Rezultati analize svjetskog tržišta su pokazali da se u razdoblju od 2006. do 2016. svjetska proizvodnja svinjskog mesa povećala za 17,2\%. $\mathrm{U}$ analiziranom razdoblju najveći svjetski proizvođači svinjskog mesa bili su Kina, SAD i Njemačka. Najveći svjetski uvoznici svinjskog mesa su Japan, Rusija, Južna Koreja, Kina i Njemačka, a najveći izvoznici SAD, Njemačka, Kanada i Danska. Prosječna svjetska potrošnja svinjskog mesa u 2016. godini iznosila je 12,4 kg/stanovniku, a na razini EU $33 \mathrm{~kg} /$ stanovniku. Najviše svinjskog mesa se konzumira u Austriji $(56,15 \mathrm{~kg} /$ stanovniku), Njemačkoj $(54,52 \mathrm{~kg} /$ stanovniku) i Španjolskoj $(52,67 \mathrm{~kg} / \mathrm{stanovniku})$. Proizvodnja svinjskog mesa u Hrvatskoj u konstantnom je padu od 2010. te je prema dostupnim podacima zabilježen pad proizvodnje do 2016. od $23 \%$. U razdoblju od 2010. do 2016. uvoz svinjskog mesa u Hrvatskoj porastao je za čak $83 \%$, a uvoz živih svinja se smanjio za $23 \%$. U promatranom razdoblju izvoz svinjskog mesa se povećao za $213 \%$, a izvoz živih svinja za 784 \%. U 2016. godini najviše svinja smo uvozili iz Nizozemske, Njemačke i Danske, a izvozili u Italiju, Mađarsku te Srbiju. U 2016. godini potrošnja svinjskog mesa iznosila je 45,9 kg/stanovniku, a samodostatnost $55 \%$. Revitalizacija svinjogojskog sektora moguća je većim ulaganjem u konvencionalnu proizvodnju te u proizvodnju specifičnih proizvoda od izvornih pasmina od kojih su neke kritično ugrožene.

Ključne riječi: svinjsko meso, tržište, Hrvatska, svijet 


\begin{abstract}
The aim of the paper was to determine the situation on the world and Croatian market of pig meat. The method of production and consumption balance was used to show the Croatian pig meat market according to the methodology of the Statistical Office of the European Communities, the data of the Central Bureau of Statistics and FAOSTAT. FAOSTAT data was used to analyze the world and EU pig meat market. The results of the world market analysis showed that in the period from 2006 to 2016 world meat production increased by $17.2 \%$. In the analyzed period, the world's largest pig meat producers were China, the USA and Germany. The world's largest importers of pork are Japan, Russia, South Korea, China and Germany, and the largest exporters are USA, Germany, Canada and Denmark. The average world consumption of pork in 2016 was $12.4 \mathrm{~kg}$ per capita and at EU level $33 \mathrm{~kg}$ per capita. Most pork meat is consumed in Austria (56.15 kg/capita), Germany $(54.52 \mathrm{~kg} /$ capita) and Spain $(52.67 \mathrm{~kg} / \mathrm{capita})$. Pig meat production in Croatia has been steadily declining since 2010, and according to available data, production fell $23 \%$ by 2016. Between 2010 and 2016, imports of pork in Croatia increased $83 \%$, while imports of live pigs decreased by $23 \%$. In the observed period, exports of pig meat increased by $213 \%$ and exports of live pigs increased $784 \%$. In 2016 Croatia imported the most pigs from the Netherlands, Germany and Denmark and exported to Italy, Hungary and Serbia. In 2016 consumption of pig meat was $45.9 \mathrm{~kg} /$ per capita and self-sufficiency was $55 \%$. Revitalization of the pig meat sector is possible by investing more in conventional production and in the specific products from domestic breeds, some of which are critically endangered.
\end{abstract}

Keywords: pork meat, market, Croatia, world

\title{
UVOD
}

S porastom stanovništva na Zemlji, raste i potreba za povećanjem količina hrane. Svinjsko meso zauzima važan udio ukupne proizvodnje i potrošnje prehrambenih namirnica u svijetu. Svinjsko meso zbog svoje dostupnosti, cijene i lakoće pripreme zauzima važan dio gastronomske ponude. Sadrži brojne važne esencijalne aminokiseline, vodu, masti, ugljikohidrate, bjelančevine te vitamine (npr. B skupine) i minerale (Cvrtila Fleck, 2012.). Opće je poznato da se u zemljama s manjom potrošnjom mesa često javljaju i problemi pothranjenosti. Zbog toga je potrošnja mesa kroz povijest bila je jedan od statusnih simbola društvenog i financijskog položaja pojedinca. $\mathrm{S}$ industrijalizacijom i rastom 
dohotka potrošnja mesa sve više raste, pa tako i potrošnja svinjskog mesa. U 2016. godini, udio svinjskog mesa u ukupnoj svjetskoj potrošnji mesa iznosio je više od 30 \% (Soare i Chiurciu, 2017.). Pojedine projekcije idu u prilog postupnom povećanju i rastu svinjogojskog sektora i većoj potrošnji te proizvodnji svinjskog mesa i u budućem razdoblju (OECD, 2017.). Sa 150 milijuna svinja i godišnjom proizvodnjom od oko 22 milijuna tona, Europska unija (EU) drugi je najveći svjetski proizvođač svinjskog mesa nakon Kine te najveći izvoznik svinjskog mesa. Samodostatnost tržišta svinjskog mesa u EU iznosi $111 \%$, pri tome se izvozi oko $13 \%$ ukupne proizvodnje. Većina izvoza svinjskog mesa ide u istočnu Aziju, posebno u Kinu.

S druge strane, Hrvatska kao članica EU je zemlja s dugom tradicijom uzgoja i držanja svinja te proizvodnjom hrane za hranidbu domaćih životinja (Kralik i sur., 2013.). Međutim, tržište svinjskog mesa u Hrvatskoj je neorganizirano te ga već duži niz godina obilježavaju negativni trendovi $u$ proizvodnji i sve većem uvozu mesa upitne kvalitete i starosti. Loši proizvodni pokazatelji, skupa proizvodnja, neudruživanje i nekonkurentnost domaćih proizvođača predstavljaju potencijalnu opasnost za nastavkom pada proizvodnje.

U nadolazećom razdoblju veliku opasnost i izazov svinjogojskom sektoru u EU, pa tako i u Hrvatskoj predstavlja afrička svinjska kuga (ASFV) (Mur i sur., 2014.). Adenaike i sur. (2017.) istraživali su prisutnost antitijela na virus afričke svinjske kuge na području Nigerije gdje je 42,86 \% uzorkovanih svinja pokazalo pozitivan rezultat na ASFV, gdje je ujedno zabilježen i visok postotak smrtnosti oboljelih svinja od $50 \%$ do $100 \%$ (Otesile i sur., 2005.). Rezultati istraživanja Mur i sur. (2014.), pokazuju da 48 \% zemalja EU ima relativno visok rizik ulaska ASFV-a na njihovo područje, a čija bi pojava donijela ogromne gubitke tržištu svinjskog mesa na području Europske unije. Hrvatska je jedina članica EU koja nije obuhvaćena u ovim istraživanjima i strategije koje razmatraju procjene kretanja proizvodnje i prodaje svinjskog mesa za Hrvatsku trebale bi u svojim analizama uključiti navedeni rizik, posebno u razdoblju kad je pitanje vremena kad će se ASFV pojaviti na našem području, a što će imati negativan utjecaj na ionako osjetljivi stočarski sektor.

Cilj rada je analizirati stanje na svjetskom tržištu svinjskog mesa $u$ razdoblju od 2006. do 2016. i hrvatskom tržištu svinjskog mesa u razdoblju od 2010. do 2016. prema dostupnim podacima. Također, u radu će se dati preporuke za povećanje konkurentnosti te smanjenje negativnih trendova na tržištu svinjskog mesa. 


\section{METODE RADA I IZVORI PODATAKA}

Za prikaz hrvatskog tržišta svinjskog mesa korištena je metoda proizvodnopotrošnih bilanci sukladno metodologiji Statističkog ureda europskih zajednica (EUROSTAT) (Doc. ASA/PE/500, Doc. ASA/PE/501). Bilanciranje je osnovna metoda koja se danas koristi za sažeti prikaz stanja na tržištu hrane u pojedinoj državi. Prema EUROSTAT-ovoj metodologiji koja je po prvi puta primijenjena u Hrvatskoj 2008. godine, temeljno pravilo bilanciranja je da se ukupna proizvodnja pojedinog proizvoda ili agregata (svinjsko meso) u jednoj godini saldira s veličinom vanjskotrgovinske razmjene i zaliha. Potom se od ukupne domaće potrošnje oduzimaju gubici i industrijska potrošnja. Dobivena veličina predstavlja raspoložive količine za ljudsku potrošnju i dijeli se s brojem potrošača u zemlji kako bi se dobila potrošnja po stanovniku. Za analizu tržišta svinjskog mesa u svijetu interpretirano je nekoliko specifičnih pokazatelja. Među pokazateljima analiziranim $u$ ovoj studiji najznačajniji su: svjetska proizvodnja svinjskog mesa, uvoz i izvoz svinjskog mesa te ukupna potrošnja svinjskog mesa u svijetu. Za analizu svjetskog i EU tržišta svinjskog mesa korišteni su podaci EUROSTAT-a i FAOSTAT-a te ekonomske projekcije potrošnje svinjskog mesa u budućnosti OECD-FAO (Omaha Economic Development Corporation i Food and Agriculture Organization of the United Nations).

\section{REZULTATI ISTRAŽIVANJA}

\section{Analiza svjetskog i europskog tržišta svinjskim mesom}

Proizvodnja svinjskog mesa u svijetu

Prateći stanje na svjetskom tržištu od 2006. do 2016. godine, razvidno je povećanje proizvodnje svinjskog mesa (Tablica 1) na godišnjoj razini (FAOSTAT, 2018.). U 2006. svjetska proizvodnja iznosila je 100.759,738 milijuna tona, a u 2016. iznosila je 118.168,709 milijuna tona. U desetogodišnjem razdoblju svjetska proizvodnja svinjskog mesa povećala se za nešto više od $17 \%$. Promatrajući proizvodnju svinjskog mesa po kontinentima u desetogodišnjem razdoblju (Slika 1), više od polovice svjetske proizvodnje odvija se u Aziji (56,4 \%), zatim slijedi Europa (24,6 \%), S. i J. Amerika $(17,5 \%)$, slijede Afrika (1,1\%) i Oceanija (0,5\%) koja u odnosu na ostatak svijeta predstavlja manje proizvodno područje. Izgledan razlog nešto slabije proizvodnje svinjskog mesa na afričkom kontinentu jest visok udio stanovništva islamske vjeroispovijesti od $47 \%$ koje ne konzumira svinjsko meso, slabiji agroekološki uvjeti za uzgoj svinja, ali i značajni problemi sa svinjskim bolestima (Riggs, 2006.). 
Tablica 1. Proizvodnja svinjskog mesa na svjetskom tržištu u razdoblju od 2006. do 2016.

Table 1 Production of pig meat on global market 2006-2016

\begin{tabular}{|c|c|}
\hline Godina (year) & Ukupno milijuna tona (million tonnes) \\
\hline 2006. & $100.759,738$ \\
\hline 2007. & $99.363,743$ \\
\hline 2008. & $103.563,925$ \\
\hline 2009. & $106.148,187$ \\
\hline 2010. & $108.973,463$ \\
\hline 2011. & $109.625,283$ \\
\hline 2012. & $113.128,957$ \\
\hline 2013. & $115.106,306$ \\
\hline 2014. & $117.263,877$ \\
\hline 2015. & $117.876,789$ \\
\hline 2016. & $118.168,709$ \\
\hline
\end{tabular}

Izvor: FAOSTAT, 2018.

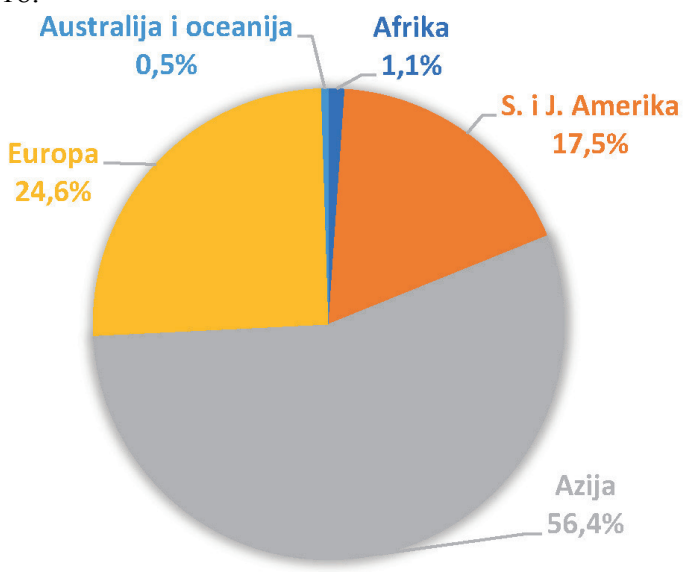

Izvor: FAOSTAT, 2018.

Slika 1. Udio proizvodnje svinjskog mesa po kontinentima (2006.-2016.)

Picture 1 Contribution of pig meat production by continents (2006-2016)

Proizvodnja svinjskog mesa po zemljama

U analiziranom razdoblju najveći svjetski proizvođači svinjskog mesa bili su Kina, SAD i Njemačka, Španjolska, Brazil, Francuska i Vijetnam koje drže 86 \% ukupne svjetske proizvodnje svinjskog mesa (FAOSTAT, 2018.). Kina je u 2016. proizvela 55.040,565 milijuna tona mesa što čini $46,5 \%$ ukupne svjetske proizvodnje. No, iako je Kina najveći svjetski proizvođač i potrošač svinjskog mesa, jedan od glavnih problema kineske proizvodnje jest kvaliteta 
i sigurnost proizvedenog mesa (Chen Ji, 2012.). Osim Kine, najveći svjetski proizvođači svinjskog mesa u 2016. su SAD koje su proizvele 11 milijuna tona (9,6 \% ukupne svjetske proizvodnje) i Njemačka koja je proizvela oko 6 milijuna tona svinjskog mesa (4,7\%). Prema OECD-FAO projekciji za razdoblje od 2016. do 2025. proizvodnja svinjskog mesa trebala bi rasti sa 118.402,000 tona u 2016 . na 131.001,000 tona u 2025., a dodatni čimbenik povećanju proizvodnje je daljnja konsolidacija sektora svinjskog mesa te se do 2025. očekuje i blagi trend porasta cijena svinjskog mesa kao i svjetske potrošnje (OECD-FAO, 2017.).

Proizvodnja svinjskog mesa u Europi

Prema podacima FAOSTAT-a (2018.), proizvodnja svinjskog mesa u 2016. u zemljama članicama EU (28) iznosila je 23.618,044 tona što je porast proizvodnje za oko $1 \%$ u odnosu na godinu ranije. Pet najvećih proizvođača u EU tijekom 2016. bili su Njemačka s ukupno proizvedenih 5.589,639 tona, zatim Španjolska s $3.947,015$ tona, Francuska s $2.185,430$ tona, slijedi Poljska s $2.008,800$ tona i Danska čija je ukupna proizvodnja navedene godine iznosila 1.579,405 tona. U 2015. proizvodnja na razini EU (28) iznosila je 23.466,859 tona, dok je u 2014. bila 22.608,582 tona. Glavni proizvođači svinjskog mesa u EU jesu Njemačka, Španjolska i Francuska i njihova proizvodnja predstavlja gotovo polovicu zaklanih svinja u Europskoj uniji. Prema podacima prikazanim u Tablici 2, proizvodnja svinjskog mesa na području cijele Europe, u razdoblju od 2006. do 2016., bilježi porast proizvodnje od $15,1 \%$, s početno proizvedenih $25.094,411$ tona mesa u 2006. godini na 28.905,673 tona u 2016. godini (FAOSTAT, 2018.).

Tablica 2. Proizvodnja svinjskog mesa u Europi za razdoblje 2006.-2016.

Table 2 Production of pig meat in Europe 2006-2016

\begin{tabular}{|c|c|}
\hline Godina (year) & Proizvodnja (mil. tona) - Production (mil.tonnes) \\
\hline 2006. & $25.094,411$ \\
\hline 2007. & $26.398,687$ \\
\hline 2008. & $26.428,874$ \\
\hline 2009. & $26.051,419$ \\
\hline 2010. & $27.034,805$ \\
\hline 2011. & $27.530,498$ \\
\hline 2012. & $27.269,745$ \\
\hline 2013. & $27.287,926$ \\
\hline 2014. & $27.435,855$ \\
\hline 2015. & $28.455,046$ \\
\hline 2016. & $28.905,673$ \\
\hline
\end{tabular}

Izvor: FAOSTAT, 2018. 
Svjetska vanjsko-trgovinska razmjena

Prema posljednje dostupnim podacima FAOSTAT-a $u$ razdoblju od 2009. do 2013. na svjetskoj razini uvezlo se $24.159,339$ tona svinjskog mesa. U promatranom razdoblju, najveći uvoznici svinjskog mesa su Japan, Rusija, Južna Koreja, Kina i Njemačka (Tablica 3). Rusija je tako u 2010. uvezla tri puta veću količinu svinjskog mesa nego godinu ranije. Uvoz svinjskog mesa u svijetu rastao je od 2009. do 2012. godine kad se bilježi značajniji pad te se od 2013. ponovno bilježi trend većeg uvoza na svjetskom tržištu, dok je Europa u 2012. i 2013. uvozila manje svinjskog mesa, a navedene godine poznate su i zbog postizanja nešto viših cijena po kilogramu mesa na razini Europske unije. Izvoz svinjskog mesa je u Svijetu dosegao svoj vrhunac u 2011. s 6.405,824 tona da bi godinu kasnije izvoz svinjskog mesa pao za $25,3 \%$. Gotovo identična situacija desila se i na europskom izvoznom tržištu gdje je 2011. izvezeno $3.894,278$ tona s drastičnim padom izvoza u 2012. na 2.261,986 tona, odnosno čak $41 \%$ manje (Slika 3) (FAOSTAT, 2018.).

Tablica 3. Najveći svjetski uvoznici svinjskog mesa (u tonama)

Table 3 Imports of top importers of meat, pork (tonnes)

\begin{tabular}{|l|c|c|c|c|c|c|}
\hline \multicolumn{1}{|c|}{ DRŽAVA } & $\mathbf{2 0 0 9 .}$ & $\mathbf{2 0 1 0 .}$ & $\mathbf{2 0 1 1 .}$ & $\mathbf{2 0 1 2 .}$ & $\mathbf{2 0 1 3 .}$ & $\begin{array}{c}\text { UKUPNO } \\
\text { (Total) }\end{array}$ \\
\hline Japan & 701.274 & 751.092 & 791.387 & 776.752 & 736.839 & $\mathbf{3 . 7 5 7 , 3 4 4}$ \\
\hline Rusija & 100.925 & 441.717 & 481.678 & 552.261 & 496.107 & $\mathbf{2 . 0 7 2 , 6 8 8}$ \\
\hline Južna Koreja & 293.945 & 288.583 & 487.017 & 380.785 & 292.746 & $\mathbf{1 . 7 4 3 , 0 7 6}$ \\
\hline Kina & 190.905 & 217.990 & 359.491 & 218.786 & 485.623 & $\mathbf{1 . 4 7 2 , 7 9 5}$ \\
\hline Njemačka & 337.330 & 356.817 & 354.456 & 144.424 & 133.075 & $\mathbf{1 . 3 2 6 , 1 0 2}$ \\
\hline Francuska & 257.368 & 266.744 & 264.317 & 208.486 & 208.826 & $1.205,741$ \\
\hline SAD & 209.730 & 232.410 & 228.249 & 231.918 & 258.927 & $1.161,234$ \\
\hline Poljska & 248.261 & 256.096 & 262.065 & 119.967 & 132.240 & 782.829 \\
\hline
\end{tabular}

Izvor: FAOSTAT, 2018. 
I. Stupnišek i sur.: Analiza svjetskog i hrvatskog tržišta svinjskog mesa

Kretanje uvoza i izvoza svinjskog mesa (u tonama) Svijet i Europa - Pork meat, export and import quantity World and Europe

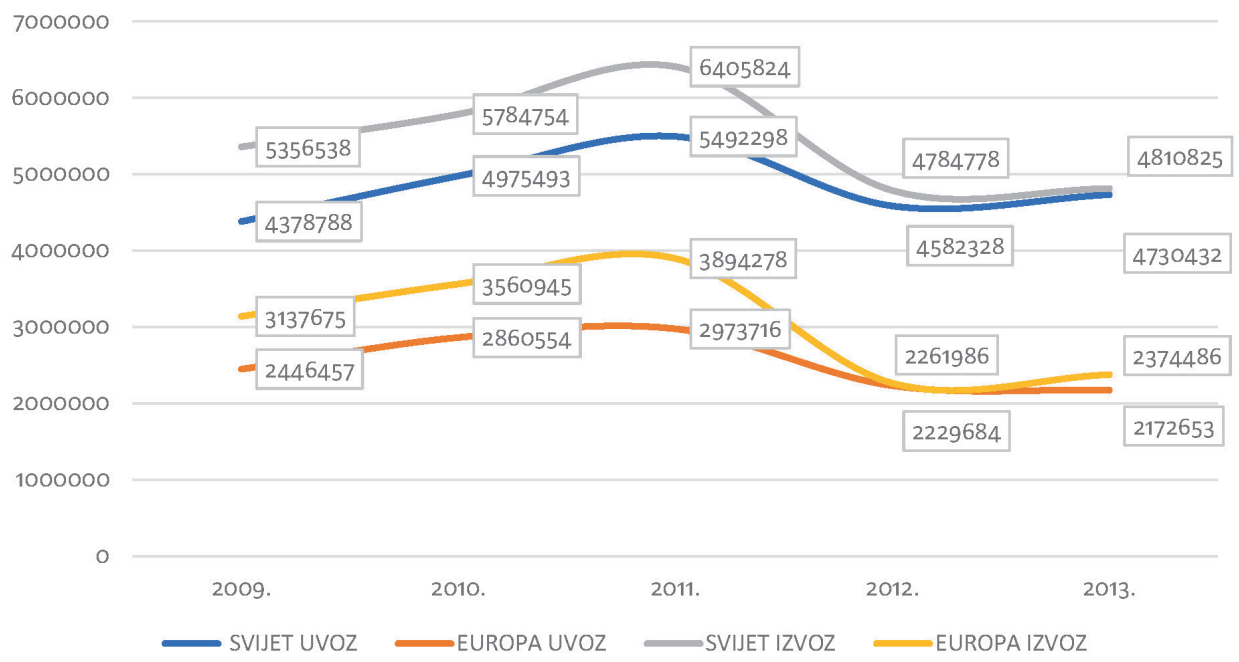

Izvor: FAOSTAT (2009.-2013.)

Slika 3. Uvoz i izvoz svinjskog mesa na svjetskom i europskom tržištu

Picture 3 Pork meat, export and import quantity World and Europe

Najveći svjetski izvoznici svinjskog mesa u petogodišnjem razdoblju od 2009.-2013. (FAOSTAT, 2018.) su SAD, Njemačka, Kanada, Danska i Španjolska (Tablica 4). Zemlje Europske unije od 2012. bilježe značajniji pad izvoza svinjskog mesa zbog ruskog embarga na prehrambene proizvode iz EU, obzirom da je Rusija bila značajnije izvozno tržište za europske zemlje. 
I. Stupnišek i sur.: Analiza svjetskog i hrvatskog tržišta svinjskog mesa

Tablica 4. Najveći svjetski izvoznici svinjskog mesa (u tonama)

Table 4 Exports of top exporters of Meat, pork (tonnes)

\begin{tabular}{|l|c|c|c|c|c|c|}
\hline \multicolumn{1}{|c|}{ DRŽAVA } & $\mathbf{2 0 0 9 .}$ & $\mathbf{2 0 1 0 .}$ & $\mathbf{2 0 1 1 .}$ & $\mathbf{2 0 1 2 .}$ & $\mathbf{2 0 1 3 .}$ & UKUPNO \\
\hline SAD & 899.204 & 912.829 & $1.177,823$ & $1.163,736$ & $1.059,091$ & $\mathbf{5 . 2 1 2 , 6 8 3}$ \\
\hline Njemačka & 835.266 & 973.191 & $1.056,470$ & 740.540 & 799.907 & $\mathbf{4 . 4 0 5 , 3 7 4}$ \\
\hline Kanada & 658.765 & 688.555 & 729.436 & 749.762 & 739.214 & $\mathbf{3 . 5 6 5 , 7 3 2}$ \\
\hline Danska & 653.212 & 700.875 & 747.358 & 356.589 & 362.058 & $\mathbf{2 . 8 2 0 , 0 9 2}$ \\
\hline Španjolska & 507.845 & 540.874 & 641.350 & 373.590 & 372.299 & $\mathbf{2 . 4 3 5 , 9 5 8}$ \\
\hline Brazil & 436.488 & 394.607 & 377.096 & 415.625 & 387.648 & $2.011,464$ \\
\hline
\end{tabular}

Izvor: FAOSTAT, 2018.

\section{Analiza potrošnje svinjskog mesa u svijetu i EU}

Prosječna svjetska potrošnja svinjskog mesa u 2006. iznosila je $11,9 \mathrm{~kg} /$ stanovniku godišnje, dok je na razini Europske unije iznosila $32,9 \mathrm{~kg} /$ stanovniku godišnje, da bi u 2016. prosječna svjetska potrošnja iznosila 12,4 kg/stanovniku, a na razini EU $33 \mathrm{~kg} /$ stanovniku (Slika 4). EU je najveći potrošač svinjskog mesa na svijetu po stanovniku. Nadalje, najveća potrošnja svinjskog mesa u promatranom razdoblju bilježi se još u Kini s $27,4 \mathrm{~kg} /$ stanovniku, Vijetnamu i Koreji s $23,2 \mathrm{~kg} /$ stanovniku te u SAD-a s $22,6 \mathrm{~kg} /$ stanovniku. U 2016. godini bilježi se povećanje svjetske potrošnje u odnosu na 2006. za $0,49 \mathrm{~kg} /$ stanovniku. U desetogodišnjem razdoblju (Slika 4) od 2006. do 2016. bilježi se porast potrošnje svinjskog mesa u svijetu, uz manje ili veće oscilacije u pojedinim godinama, a najveći porast je ostvaren u Vijetnamu, Koreji i Kini (OECD-FAO, 2017.). Prema dostupnim podacima (Slika 5), u Europskoj uniji od 2008. do 2015. prosječno najveća potrošnja svinjskog mesa bilježi se u Austriji (56,15 kg/stanovniku), Njemačkoj (54,52 kg/stanovniku), Poljskoj (52,11 kg/stanovniku), Španjolskoj $(52,67 \mathrm{~kg} /$ stanovniku) i Češkoj $(43,76 \mathrm{~kg} / \mathrm{stanovniku}) . \mathrm{U}$ 2015. godini u EU ukupna prosječna potrošnja svinjskog mesa iznosila je 40,9 kg/stanovniku. 


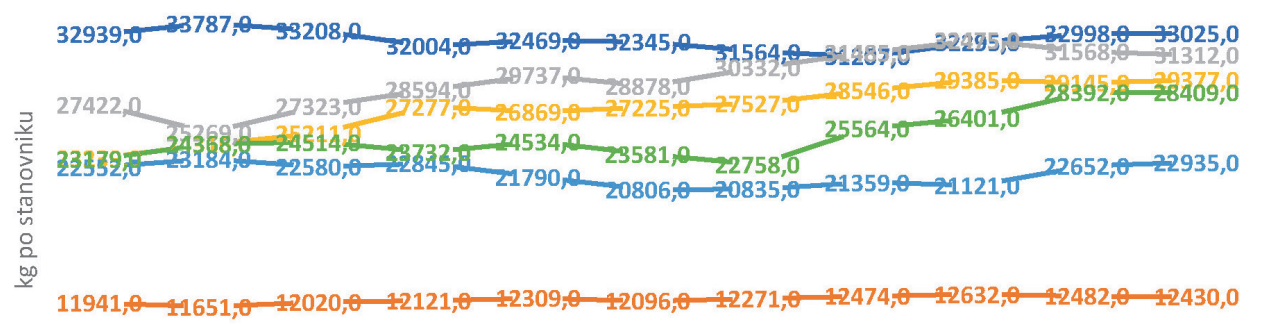

2006. 2007. 2008. 2009. 2010. 2011. 2012. 2013. 2014. 2015.2016. Izvor: OECD-FAO (2017.), Meat consumption (indicator)

Slika 4. Svjetska potrošnja svinjskog mesa za razdoblje 2006.-2016., te pet najvećih svjetskih potrošača

Picture 4 World consumption of pork meat for the period 2006-2016 and the top five world consumers

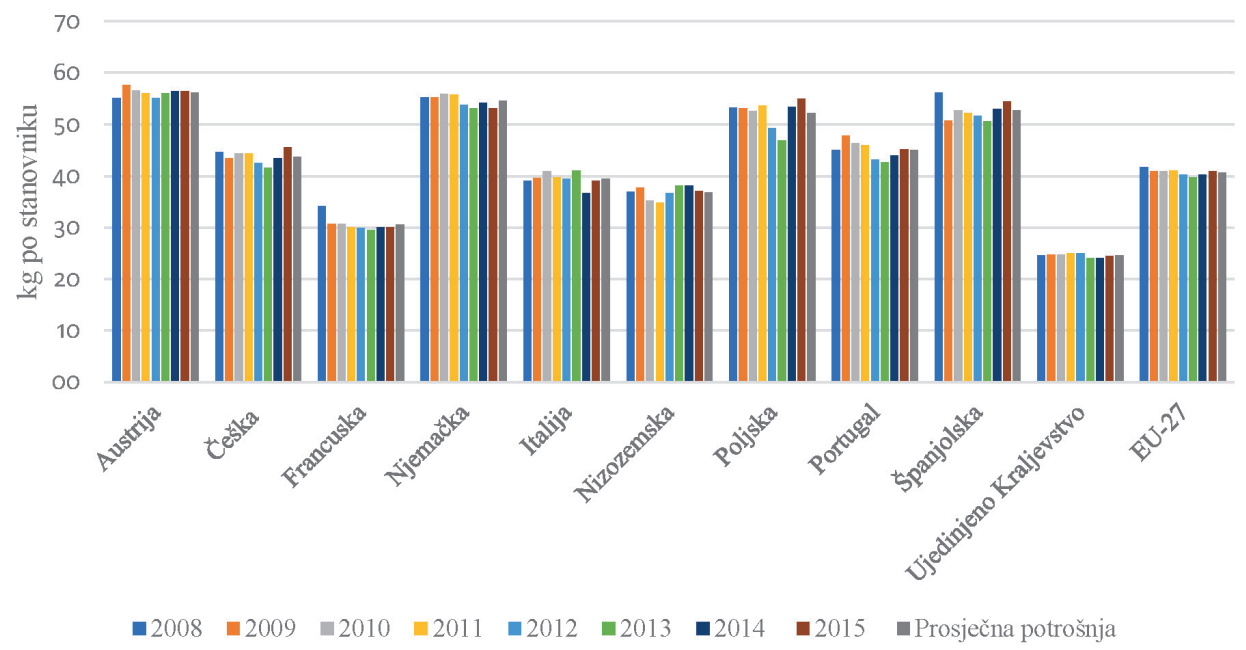

Izvor: AHDB (dostupni podaci od 2008. do 2015.)

Slika 5. Kretanje konzumacije svinjskog mesa u EU 27

Picture 5 Per capita pig meat consumption in EU 27 member state 
U posljednjem desetljeću proizvodnja svinjskog mesa u Hrvatskoj kontinuirano pada. Najveća proizvodnja svinjskog mesa iznosila je 136 tisuća tona u 2010. godini, da bi se potom kontinuirano smanjivala te 2015. godine dosegla najnižu razinu od 96 tisuća tona. Uvoz živih svinja se smanjio s 13 tisuća tona na 10,8 tisuća tona u 2016., dok se izvoz živih svinja u promatranom razdoblju povećao za rekordnih $784 \%$. U 2016. godini najviše svinja smo uvozili iz Nizozemske, Njemačke i Danske. Prema podacima DZS u Hrvatsku je 2016. godine iz Nizozemske uvezeno 3,99 tisuća tona živih svinja u vrijednosti od 7,5 mil. EUR-a, iz Njemačke 2,27 tisuća tona u vrijednosti 4,37 mil. EUR-a te iz Mađarske 1,95 tisuća tona $u$ vrijednosti od 3,59 mil. EUR-a. (Tablica 6). Najveće količine živih svinja u 2016. godini izvezene su u Italiju (8,67 tisuća tona) u vrijednosti 7,5 mil. EUR-a, Mađarsku (7,27 tisuća tona) u vrijednosti 4,37 mil. EUR-a te Srbiju (0,28 tisuća tona) u vrijednosti 455 tis. EUR-a. U 2016. godini potrošnja svinjskog mesa iznosila je $45,9 \mathrm{~kg} /$ stanovniku što je povećanje za $3,44 \%$ u odnosu na 2010. godinu. Samodostatnost svinjskog mesa se smanjila sa $70 \%$ na $55 \%$. Najveća je bila početkom, a najmanja krajem promatranog razdoblja. Kad se uzmu u obzir izdaci potrošnje za meso i pripravaka od mesa i prosjeci po kućanstvima u Republici Hrvatskoj za 2014. godinu, 20,7 \% budžeta se izdvaja za svinjsko meso (DZS, 2016.), a tek neznatno više, $21,4 \%$ se izdvaja za meso peradi. Sukladno navedenom, u 2017. godini se u prvom kvartalu najviše uvozilo svinjsko meso (DZS, 2016.). 
I. Stupnišek i sur.: Analiza svjetskog i hrvatskog tržišta svinjskog mesa

Tablica 5. Proizvodno potrošna bilanca svinjskog mesa u RH za razdoblje od 2010. do 2016.

Table 5 Consumption balance of pork meat in Croatia for the period 2010-2016

\begin{tabular}{|c|c|c|c|c|c|c|c|}
\hline $\begin{array}{c}\text { OSNOVE } \\
\text { PROIZVODNJE }\end{array}$ & 2010. & 2011. & 2012. & 2013. & 2014. & 2015. & 2016. \\
\hline Klanje (000 kom) & $2.158,609$ & $1.775,277$ & $1.684,035$ & $1.476,971$ & $1.362,811$ & 1400,113 & 1458,334 \\
\hline $\begin{array}{l}\text { Prosječna težina } \\
\text { trupa (kg) }\end{array}$ & 68,349 & 82,497 & 75,325 & 72,080 & 70,191 & 67,146 & 67,212 \\
\hline $\begin{array}{l}\text { Neto težina zaklanih } \\
\text { životinja }(1000 \mathrm{t})\end{array}$ & 147,538 & 146,455 & 126,850 & 106,460 & 95,657 & 94,012 & 98,018 \\
\hline \multicolumn{8}{|l|}{ BILANCA (1000 t) } \\
\hline $\begin{array}{l}\text { DOMAĆA } \\
\text { PROIZVODNJA } \\
\text { MESA (GIP) } \\
\end{array}$ & 136,394 & 137,697 & 121,979 & 105,251 & 102,164 & 96,636 & 104,818 \\
\hline $\begin{array}{l}\text { UVOZ ŽIVIH } \\
\text { ŽIVOTINJA }\end{array}$ & 13,046 & 12,407 & 10,850 & 7,015 & 8,600 & 9,886 & 10,008 \\
\hline - iz EU & 13,046 & 12,407 & 10,850 & 6,999 & 8,600 & 9,886 & 10,008 \\
\hline $\begin{array}{l}\text { IZVOZ ŽIVIH } \\
\text { ŽIVOTINJA } \\
\end{array}$ & 1,902 & 3,649 & 5,979 & 5,806 & 15,106 & 12,510 & 16,8078 \\
\hline - uEU & 0,000 & 0,000 & 0,000 & 0,180 & 1,135 & 7,008 & 16,3896 \\
\hline $\begin{array}{l}\text { NETO PROIZVODNJA } \\
\text { MESA }\end{array}$ & 147,538 & 146,455 & 126,850 & 106,460 & 95,657 & 94,012 & 98,018 \\
\hline UVOZ MESA & 60,914 & 63,337 & 68,825 & 80,926 & 98,400 & 112,595 & 111,412 \\
\hline - iz EU & 54,135 & 61,049 & 65,852 & 80,019 & 98,372 & 112,563 & 111,22 \\
\hline RESURSI & 208,452 & 209,792 & 195,675 & 187,386 & 194,057 & 206,607 & 209,430 \\
\hline IZVOZ MESA & 5,723 & 5,652 & 7,199 & 8,450 & 6,768 & 11,554 & 17,909 \\
\hline - u EU & 0,228 & 0,381 & 0,389 & 0,955 & 3,237 & 6,854 & 11,6595 \\
\hline PROMJENE ZALIHA & 6,748 & $-2,742$ & 0,476 & 0,703 & $-0,627$ & 0,184 & $-0,009$ \\
\hline \begin{tabular}{|l|} 
DOMAĆA \\
POTROŠNJA \\
\end{tabular} & 195,981 & 206,882 & 187,999 & 178,233 & 187,916 & 194,869 & $\mathbf{1 9 1 , 5 3 0}$ \\
\hline \begin{tabular}{|l|} 
LJUDSKA \\
POTROŠNJA
\end{tabular} & 195,981 & 206,882 & 187,999 & 178,233 & 187,916 & 194,869 & 191,530 \\
\hline - po glavi stanovnika/kg & 44,360 & 48,281 & 44,059 & 41,878 & 44,699 & 46,353 & 45,886 \\
\hline $\begin{array}{l}\text { STUPANJ } \\
\text { SAMODOSTATNOSTI }\end{array}$ & 70 & 67 & 65 & 59 & 54 & 50 & 55 \\
\hline
\end{tabular}

Izvor: Izračunato na temelju podataka DZS RH, 2018. 
I. Stupnišek i sur.: Analiza svjetskog i hrvatskog tržišta svinjskog mesa

Tablica 6. Hrvatski uvoz i izvoz živih životinja (svinja) prema zemljama za 2016. g.

Table 6 Croatian import and export of live pig animals by countries for 2016

\begin{tabular}{|c|c|c|c|c|c|}
\hline \multirow{2}{*}{ Naziv zemlje } & UVOZ 2016. & UVOZ 2016. & \multirow{2}{*}{ Naziv zemlje } & IZVOZ 2016. & IZVOZ 2016. \\
\hline & $000 \mathrm{t}$ & EUR & & $000 \mathrm{t}$ & EUR \\
\hline Nizozemska & 3,99 & 7.505 .703 & Italija & 8,67 & 13.680 .422 \\
\hline Njemačka & 2,27 & 4.367 .074 & Mađarska & 7,27 & 10.948 .068 \\
\hline Mađarska & 1,95 & 3.592 .350 & Srbija & 0,28 & 445.104 \\
\hline Danska & 1,66 & 4.266 .267 & Nizozemska & 0,21 & 339.338 \\
\hline Belgija & 0,06 & 237.303 & $\begin{array}{l}\text { Ujedinjena } \\
\text { Kraljevina }\end{array}$ & 0,14 & 371.961 \\
\hline Ostale zemlje & 0,08 & 256.557 & ostale & 0,27 & 470.679 \\
\hline $\begin{array}{l}\text { Ukupno } \\
\text { (Total) }\end{array}$ & 10,01 & 20.225 .254 & $\begin{array}{l}\text { Ukupno } \\
\text { (Total) }\end{array}$ & 16,84 & 26.255.572 \\
\hline
\end{tabular}

Izračunato na temelju podataka DZS, 2016.

\section{ZAKLJUČAK I DISKUSIJA}

Rezultati analize svjetskog tržišta su pokazali da se u razdoblju od 2006. do 2016. svjetska proizvodnja svinjskog mesa povećala za 17,2\%. U analiziranom razdoblju najveći svjetski proizvođači svinjskog mesa bili su Kina, SAD i Njemačka. Kina se kao najveći svjetski proizvođač i potrošač susreće $s$ problemima $\mathrm{u}$ proizvodnji, poput kvalitete finalnog proizvoda i sigurnosti proizvedenog mesa. Glavni proizvođači svinjskog mesa u EU su Njemačka, Španjolska i Francuska. S druge strane, u Hrvatskoj je proizvodnja svinjskog mesa u konstantnom padu od 2010. te je prema dostupnim podacima zabilježen pad proizvodnje do 2016. od $23 \%$. U razdoblju od 2010. do 2016. uvoz svinjskog mesa u Hrvatskoj porastao je za $83 \%$, a uvoz živih svinja se smanjio za $23 \%$. U 2016. godini najviše svinja smo uvozili iz Nizozemske, Njemačke i Danske, a izvozili u Italiju, Mađarsku te Srbiju. U 2016. godini bilježi se povećanje svjetske potrošnje svinjskog mesa u odnosu na 2006. za $0,49 \mathrm{~kg} /$ stanovniku te prosječna potrošnja svinjskog mesa iznosi $12,4 \mathrm{~kg} /$ stanovniku. Najveći porast potrošnje svinjskog mesa zabilježen je u azijskim zemljama. U Europskoj uniji najveća potrošnja svinjskog mesa bilježi se u Austriji (56,15 kg/stanovniku), Njemačkoj (54,52 kg/stanovniku), Poljskoj $(52,11 \mathrm{~kg} / \mathrm{stanovniku})$, Španjolskoj $(52,67 \mathrm{~kg} /$ stanovniku) i Češkoj (43,76 kg/stanovniku). Potrošnja svinjskog mesa u Hrvatskoj u 2016. iznosila je 
približno $46 \mathrm{~kg} /$ stanovniku. Globalno promatrajući, potrošnja mesa je općenito pod utjecajem niza čimbenika, kao što su: potrošačke navike, životni standard, proizvodnja mesa i potrošačke cijene itd. Povećanje potrošnje mesa u nekim zemljama je uglavnom vezano uz povećanje dohotka stanovništva i urbanizaciju. Potrošači mijenjaju svoje potrošačke navike te je posljednjih godina prehrana $\mathrm{s}$ visokim udjelom proteina, kao što je meso, među najpopularnijima (Soare and Chiurciu, 2017.).

Obzirom na pad proizvodnje, veliki uvoz i nisku samodostatnost od svega $55 \%$ u 2016. godini, Hrvatska treba razviti bolju strategiju za povećanje proizvodnje svinjskog mesa jer zbog svojih agroekoloških uvjeta ima preduvjete u kojima bi se svinjogojska proizvodnja potencijalno mogla (trebala) širiti i rasti. Osim strateškog porasta konvencionalne proizvodnje i bolje koordiniranog izvoza, prilike leže i u proizvodnji specifičnih proizvoda od izvornih pasmina te posebice u ekološkoj proizvodnji s obzirom da se trendovi tržišta u Europi razvijaju u tom smjeru za sve poljoprivredne proizvode. Jačim udruživanjem, boljom strategijom i boljim marketinškim pristupom konvencionalna proizvodnja i izvoz svinjskog mesa u Republici Hrvatskoj mogli bi se povećati. Ujedno, jedni od najvećih europskih potrošača svinjetine jesu geografski Hrvatskoj relativno bliske zemlje poput Austrije, Italije i Njemačke. Kralik i sur. (2013.) kao priliku za svinjogojski sektor vide u korištenju novčanih sredstava iz mjera ruralnog razvoja koja bi mogla revitalizirati proizvodnju svinja u Hrvatskoj, čime bi se razvila prerađivačka industrija, otvorila nova radna mjesta, ali i osigurala samodostatnost u opskrbi svinjskim mesom. Izlaz za male proizvođače vide u udruživanju, zajedničkom nastupu na tržištu, a kao prednost manjih proizvođača navode bolju fleksibilnost i organizaciju posla $u$ odnosu na velike proizvođače te jeftinijoj radnoj snazi. Salajpal i Mahnet (2016.) predlažu konkretne mjere za zaustavljanje pada u svinjogojskoj proizvodnji i stvaranje pretpostavki za njeno povećanje. Neke od mjera koje navode su skraćivanje rokova plaćanja zbog povećanja likvidnosti, donošenje mjera za poticanje klanja u RH, promjene u poreznom sustavu (PDV), označavanje proizvoda, zatim reviziju programa ruralnog razvoja za sektor svinjogojstva, poticanje izvoza na treća tržišta, ali i poticanje ulaganja u obnovljive izvore energije na farmama. Boljim marketinškim isticanjem prihvatljivijih i specifičnih uzgojnih uvjeta u proizvodnji svinjskog mesa, ali i proizvoda od svinjskog mesa, dobili bi se proizvodi vrhunske kvalitete. Jedna od prilika za proizvođače u Hrvatskoj mogla bi biti i u ekološkoj proizvodnji svinja. Sve više javno mijenje u Europi jest takvo da nije osobito sklono intenzivnoj proizvodnji svinja te se sve više zalaže za veću dobrobit životinja i 
smanjenje problema vezanih uz zaštitu okoliša (Kanis i sur., 2003.). Proizvodi proizvedeni prema smjernicama za ekološki uzgoj bi se marketinški u mnogočemu razlikovali od onih intenzivno proizvedenih, a porast proizvodnje i prodaje navedenih proizvoda uz jačanje lokalne ekonomije u kombinaciji $\mathrm{s}$ održavanjem lokalne kulture ili, primjerice, specifičnih tradicionalnih proizvoda i turizma, doprinijelo bi dodatnom zapošljavanju i smanjenju trenda odlaska sa sela. Jedna od autohtonih pasmina za proizvodnju specifičnih proizvoda je i turopoljska svinja čiju kvalitetu mesa su potvrdili Đikić i sur. (2010.). Ispravnim marketinškim pristupom ovakvi podaci mogli bi, s obzirom na navedene EU trendove percepcije potrošača, doprinijeti razvoju specijalnog dijela tržišta svinjskog mesa vezanog uz tradicijske proizvode. Prema Grgiću i sur. (2015.) preporuka OPG-ima je da usmjere proizvodnju na odabrane pasmine svinja te na udruživanje, dok su tipični proizvodi od autohtonih pasmina svinja dobar primjer jake suradnje između javnih institucija, proizvođača i znanstvenika. Navedene prednosti potrebno je znanstveno istražiti kako bi se utvrdio pravi potencijal.

\section{LITERATURA:}

1. Adenaike E. A., Tekdek L. B., Kazeemand H. M., Simon A. Y. (2017.): Antibody detection in suspected carriers of African swine fever virus in ado local government area of Benue State, Nigeria. Journal of Animal Production Research, 29 (1): 430-436.

2. Chen Ji, (2012.): Governance Structure Choices in Supply Chain Mnagement Evidence from Spanish and Chinese Pork Chain Cases. Doctoral thesis.

3. Državni zavod za statistiku Republike Hrvatske (2014.). Rezultati ankete o potrošnji kućanstava u 2014. Statistička izvješća. ISSN 1331-5146, Zagreb, 2016.

4. Đikić M., Salajpal K., Karolyi D., Đikić D., Rupić V. (2010.). Biological characteristics of Turopolje pig breed as factors in renewing and preservation of population. Stočarstvo: Časopis za unaprjeđenje stočarstva, 64 (2-4), 79-90.

5. Grgić I., Zrakić M., Hadelan L. (2015.): Proizvodno - potrošna bilanca svinjskog mesa u Hrvatskoj. Meso: prvi hrvatski časopis o mesu, XVII.(2), 138-144.

6. Kanis E., Groen AB F., K. H. de Greef (2003.): Societal Concerns about Pork and Pork Production and Their Relationships to the Production System. Journal of Agricultural and Environmental Ethics, Volume 16 (2), 137 - 162. 
I. Stupnišek i sur.: Analiza svjetskog i hrvatskog tržišta svinjskog mesa

7. Kralik G., Margeta V., Luković Z., Kralik I. Stanje i smjernice razvoja svinjogojstva s posebnim osvrtom na istočnu Hrvatsku. Stočarstvo 67:2013 (4) $151-159$.

8. Mahnet Ž., Klišanić V., Lubina Malus N., Prpić V., Uzelac M., Hunjak M. (2017.): Svinjogojstvo, Izvješće za 2016. godinu. Hrvatska poljoprivredna agencija.

9. Mur L., Martínez-López B., Costard S., A. de la Torre, Jones B. A., Martínez M., Sánchez-Vizcaíno F., Jesús Muñoz M., Pfeiffer D. U., Manuel SánchezVizcaíno J., Wieland B. (2014.): Modular framework to assess the risk of African swine fever virus entry into the European Union. BMC Veterinary research, 10:145.

10. Otesile E. B., Ajuwape A. T. P., Odemuyiwa S. O., Akpavie S. O., Olaifa A. K., Odaibo G. N. (2005.): An Outbreak of African swine fever in Nigeria, Journal of Tropical Livestock Science, 58 (1-2): 21-26.

11. Riggs T. (2006.): Worldmark Enciclopedia of Religious Practices: Religions and and Denominations, 453-492.

12. Salajpal K., Mahnet Ž. (2016.): XII. Savjetovanje uzgajivača svinja u RH. Mogućnosti razvoja svinjogojske proizvodnje u Republici Hrvatskoj do 2020. s pogledom na 2030. Powerpoint prezentacija (http://www.hpa.hr/wpcontent/uploads/2016/06/Mogu\%C4\%87nosti-razvoja-svinjogojske-

proizvodnje-u-Republici-Hrvatskoj-do-2020.-s-pogledom-na-2030.-godinu.pdf

13. Soare E., Chiurciu I. A. (2017.): Study on the pork market worldwide. Scientific papers: management, economic engineering in agriculture \& rural development, 17(4).

\section{Internet stranice:}

http://ec.europa.eu/eurostat/tgm/table.do?tab=table\&init=1\&language=en\&pco $\mathrm{de}=\operatorname{tag} 00042 \&$ plugin $=1$ Eurostat, Production of meat: pigs. Pristupljeno 15.09.2018.

http://pork.ahdb.org.uk/prices-stats/consumption/eu-per-capita-consumption/ Pristupljeno 17.09.2018.

http://pork.ahdb.org.uk/prices-stats/news/2016/march/eu-pig-meatconsumption-rises-in-2015/. Pristupljeno 22.09.2018.

http://www.fao.org/faostat/en/\#data/QL Faostat, Livestock Primary, Meat Pig, World Total (2006.-2016.). Pristupljeno 03.10.2018.

http://www.fao.org/faostat/en/\#data/QL Faostat, Livestock Primary, Meat Pig, Europe Total (2006.-2016.). Pristupljeno 03.10.2018. 
http://www.fao.org/faostat/en/\#data/QL Faostat, Livestock Primary, Meat Pig, Croatia (2006.-2016.). Pristupljeno 11.10.2018.

https://data.oecd.org/agroutput/meat-consumption.htm OECD (2017.), Meat consumption (indicator). doi: 10.1787/fa290fd0-en. Pristupljeno 05.10.2018.

https://ec.europa.eu/agriculture/sites/agriculture/files/marketobservatory/meat/pigmeat/doc/dashboard-pig_en.pdf DG AGRI Dashboard: Pigmeat. Pristupljeno 03.10.2018.

http://hig-hrane02.vef.unizg.hr/wp-uploads/2012/10/KEMIJSKI_SASTAV_MESA-prof-Cvrtila-Fleck.pdf. Pristupljeno 19.09.2018.

Adresa autora - Author's address:

Ivan Stupnišek, mag. ing. agr., e-mail: ivan.stupni@gmail.com, doktorand poslijediplomskog doktorskog studija Poljoprivredne znanosti, mob: 091/130 8030

Doc. dr. sc.Željka Mesić, e-mail: zmesic@agr.hr

Zavod za marketing u poljoprivredi,

Agronomski fakultet Sveučilišta u Zagrebu,

Svetošimunska c. 25. Zagreb,; tel: 01/2393 641
Primljeno- Received:

02.07.2018. 
